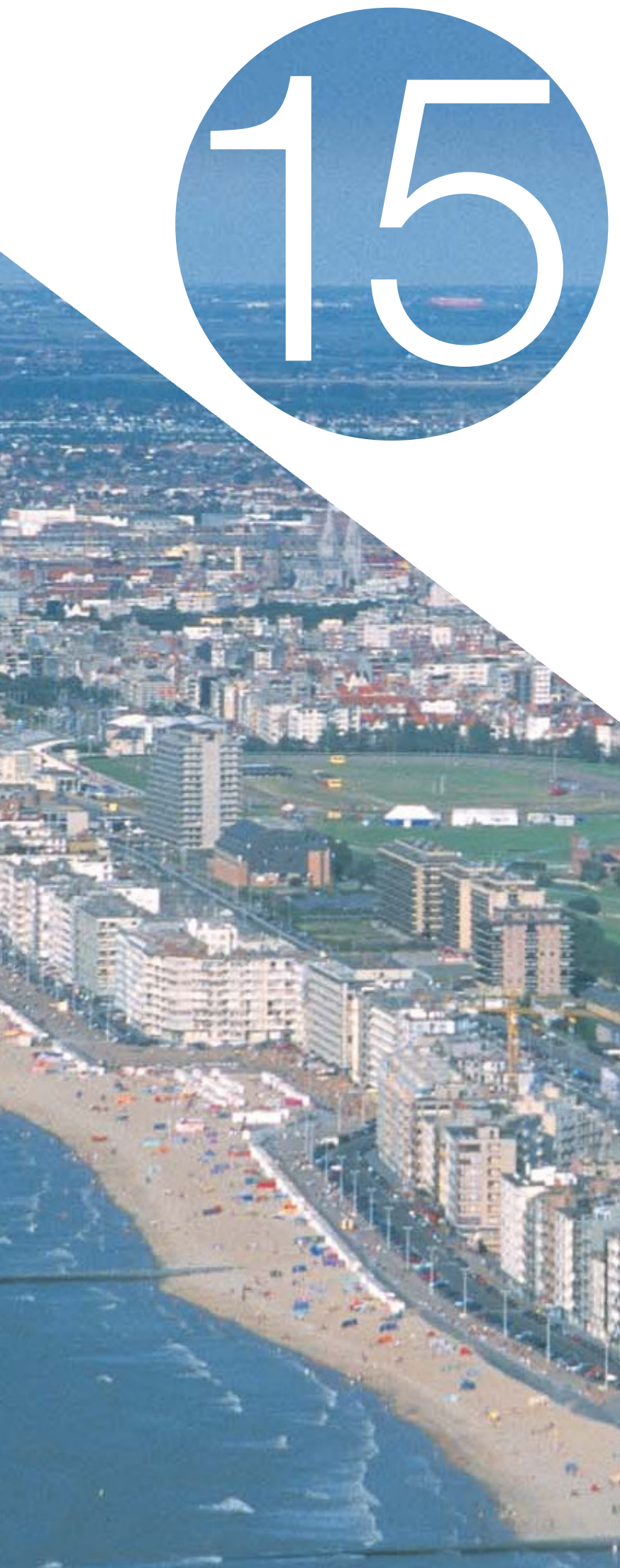

\title{
Integrated coastal zone management
}

\section{Authors}

Hannelore Maelfait ${ }^{1}$

Kathy Belpaeme ${ }^{1}$

Ann-Katrien Lescrauwaet ${ }^{2}$

\section{Reviewers}

Ann Cliquet $^{3}$

Michaël Kyramarios ${ }^{4}$

Wendy Bonne ${ }^{4,5}$

${ }^{1}$ Coordination Centre for Integrated Coastal Zone Management

2 Flanders Marine Institute (VLIZ)

${ }^{3}$ Maritime Institute, Ghent University

${ }^{4}$ FPS Health, Food Chain Safety and Environment, DG for Environment, Marine Environment Department

${ }^{5}$ Current affiliation: VLIZ - JPI-Oceans

Citation:

Maelfait, H., Belpaeme, K., Lescrauwaet, A.K., 2013. Integrated coastal zone management. In: Lescrauwaet, A.K. Pirlet, $H$., Verleye, T., Mees, J., Herman, R. (Eds.), Compendium for Coast and Sea 2013: integrating knowledge on the socio-economic, environmental and institutional aspects of the Coast and Sea in Flanders and Belgium. Oostende, Belgium, p. 251-260. 
Integrated Coastal Zone Management (ICZM) or Integrated Coastal (Zone) Management (ICM), coastal zone management for short, represents "a continuous process with the general aim of implementing sustainable development in coastal zones through optimal management of human activities in this area in order to improve the state of the coastal environment and maintain its diversity" (European Commission EC, 1999). The European Union originally focused on ICZM in a recommendation (non-legally binding policy), which aimed at developing a common vision in drafting and implementing national strategies for ICZM. Out of the 20 coastal EU Member States, nine countries - representing for $64 \%$ of the European coastline ${ }^{1}$ - already had a national ICZM strategy in 2005. Belgium, as well as seven other Member States (all in all 18\% of the EU coastline), does not have an ICZM strategy but performs additional actions for achieving integrated coastal zone management within the existing policies and legislation. Meanwhile, significant progress has been made in the legal anchoring of ICZM at a regional level in the EU. Moreover, the validity of the recommendation expired in 2006 and the European ICZM instrument was subject to a review. An evaluation was carried out after 10 years of ICZM in Belgium as well (Belpaeme 2011 208453). On 12 March 2013, the EC gave its approval for a draft proposal for a Directive establishing a framework for maritime spatial planning and ICZM (see also theme Marine Spatial Planning). The proposed instrument will require Member States to establish strategies for ICZM, building on the principles and elements of the Council Recommendation on ICZM in 2002. In 2010, the EC also signed the ICZM Protocol for the Mediterranean. This protocol is a legally binding document for all Member States.

\subsection{Policy context}

In the global context, ICZM was put on the agenda at the UN World Conference on sustainable development (Rio, 1992). In chapter 17 of Agenda 21 (a UN action plan for sustainable development, adopted at the Rio Conference in 1992) the objectives for the protection of oceans, seas and coastal areas were developed. A specific reference to the importance of an integrated approach was included. UNESCO adopted Integrated Coastal Area Management (ICAM) as an independent programme in the $19^{\text {th }}$ session of the Intergovernmental Oceanographic Commission (IOC) meeting in 1997. The objective of this programme is to support the IOC Member States in their efforts to develop marine scientific and technological capabilities with regard to ICZM, following Agenda 21.

In the European Member States, ICZM is mainly stimulated by the Recommendation concerning the implementation of Integrated Coastal Zone Management in Europe (2002/413/EC). The 'ICZM recommendation' serves as a policy framework to provide a common vision and standard for all Member States. The European 'ICZM recommendation' (2002/413/EC) was preceded by a series of European charters and decisions focused on spatial planning and the protection of the coastline (table 1), and was drafted in response to Chapter 17 of Agenda 21.

Prior to the European recommendation, Belgium played an active role inter alia by participating in the 'TERRA CZM' project (commissioned by the European Commission (1996-1999)) to gather technical information regarding ICZM, and to stimulate a wider debate on sustainable coastal management through the Demonstration programmes ${ }^{18627}$. Since the adoption of the recommendation - a non-binding legal instrument - significant progress has been made at the level of the regional seas in the development and endorsement of legally binding regulations on ICZM (ICZM Protocol to the Barcelona Convention on Integrated Coastal Zone Management for the Mediterranean, regulations which are part of HELCOM for the Baltic sea, and the Bucharest Convention for the Black Sea). In the recommendation, the EU invited the Member States to develop national strategies and measures and to report about the progress by 2006 (COM (2007) 308).

In order to further promote sustainable development of coastal areas, the European Commission approved a draft proposal for a directive establishing a framework for maritime spatial planning and integrated coastal zone management on 12 March 2013 (COM (2013) 133). The proposed instrument will require the Member States to develop ICZM strategies, building on the principles and elements of the Council Recommendation on ICZM in 2002 (2002/413/EC) and of the Protocol of the Barcelona Convention for the ICZM, as ratified by the EU in 2010.

In Belgium, the Coordination Centre for Integrated Coastal Zone Management is the contact point for ICZM. The Coordination Centre was established in 2001 - a year before the ICZM recommendation - as a project of the 'Objective 2' programme of the EC. After an initial assessment in 2006, the partners decided to sign the 'ICZM Protocol', which confirmed the role of the Coordination Centre as an important instrument for ICZM in Belgium. The Protocol was signed in 2007 by the Provincial Government (Province of West Flanders), the Agency for Nature and Forest (ANB,

$\overline{1}$ coastline as defined by EUROSION: http://www.eurosion.org 


\section{YEAR POLICY INSTRUMENT}

1973 Decision (73) 29 of the European Council

1981 European Coastal Charter ${ }^{226578}$, prepared by the Conference of Peripheral Maritime Regions of Europe

1982 Resolution of the EU Parliament to support the European Coastal Chapter

1983 European Charter for Regional Planning (CEMAT)

1992 Chapter 17 of Agenda 21

1992 Resolution of the European Council on the future Community policy concerning the European coastal zone $(92 / C 59 / 01)$

1994 Resolution of the European Council on a Community strategy for integrated coastal zone management (94/C 135/02)

1996- The European Commission launched a

1999 Demonstration programme ${ }^{18627}$ on sustainable coastal management

1999 European Council: Model Law on Coastal protection 64989

1999 European Council: Code of conduct for coastal zones 20650

2000 A proposal to the EU Parliament and the EU Council for an EU Recommendation on Integrated Coastal Zone Management in Europe (COM (2000) 545)

2000 Communication from the Commission to the Council and the European Parliament on Integrated Coastal Zone Management (COM (2000) 547)

2001 Coordination Centre for Integrated Coastal Zone Management

2002 Recommendation concerning the implementation of Integrated Coastal Zone Management (ICZM) in Europe approved by the European Parliament and the European Council, 30 May 2002 (2002/413/EC)

2002 The 6th Environment Action Programme of the European Community, 2002-2012 (Decision 1600/2002/EC)

2006 National reporting by Member States on the progress of the implementation of ICZM

2007 Communication from the Commission. Report to the European Parliament and the Council: An evaluation of Integrated Coastal Zone Management (ICZM) in Europe (COM (2007) 308)

\section{OBJECTIVE/DESCRIPTION}

Decision concerning the protection of the coastline.

Outlines the basic principles for integrated management of coastal areas.

Supports the principles as described in the 'Coastal Charter'. Both the Charter and Decision (73) 29 underline the need for integrated coastal planning in Europe.

Emphasises the need for spatial planning in European coastal areas.

Precursor of a specific European policy on ICZM. Calls for the coastal states to draw up ICZM strategies. Chapter 10 of Agenda 21 also stresses the importance of integrated and sustainable management of land use.

Partly in succession to Agenda 21, the European Council recognizes the need for an integrated approach in addressing the challenges of coastal management, and urges the Commission to make a proposal for action in Europe.

The EU requests the Member States to protect the coastal zone through a common strategy for integrated management of coastal zones.

35 projects are approved and 6 thematic studies are drafted. The Flemish Region conducts the project TERRA-CZM 'to gather technical information regarding ICZM, and to stimulate a wider debate'.

A proposal for elements of a future model law for coastal protection.

A proposal for 'good practice' concerning ICZM.

Proposed strategy to promote a common approach at European level with regard to the planning and management of the coastal zone.

In the framework of the European 'Objective 2 ' programme for coastal areas, the Coordination Centre for Integrated Coastal Zone Management is founded in Belgium.

Recommendation based on Article 175 of the European Treaty that gives the European Council the possibility to adopt measures in order to protect the environment. In this Recommendation, the EU Member States are requested to develop a national strategy for their coastal policy which takes into account the sustainable development strategy. Furthermore, the preparation of a national inventory of major actors, laws and institutions related to the management of the coastal area is requested.

Confirms ICZM as a priority action, cf. Article 3.10 and 6.2 (g).

Belgian report on the implementation of the ICZM Recommendation ${ }^{101811}$

Evaluation of the national implementation of ICZM. 


\begin{tabular}{|lll|}
\hline YEAR & \multicolumn{1}{c|}{ POLICY INSTRUMENT (continuation) } & \multicolumn{1}{c}{ OBJECTIVE/DESCRIPTION } \\
\hline 2008 & $\begin{array}{l}\text { Marine Strategy Framework Directive (Directive } \\
\text { 2008/56/EG) }\end{array}$ & $\begin{array}{l}\text { Directive establishing a framework for common measures with } \\
\text { regard to the policy on the marine environment. }\end{array}$ \\
2008 & $\begin{array}{l}\text { Roadmap for Maritime Spatial Planning (MSP). } \\
\text { Communication from the Commission (COM (2008) } \\
791)\end{array}$ & $\begin{array}{l}\text { Proposal by the European Commission to apply common } \\
\text { principles for MSP in the EU, with reference to the relationship } \\
\text { between ICZM and MSP (section 5.9). }\end{array}$ \\
\hline 2011 & $\begin{array}{l}\text { Evaluation of 10 years of ICZM in Belgium } \\
\text { (September 2011) }\end{array}$ & $\begin{array}{l}\text { Report '10 jaar Coördinatiepunt, een kwestie van evenwicht' } \\
\text { (Belpaeme 2011 208453) }\end{array}$ \\
$2011-$ & $\begin{array}{l}\text { Impact analysis, Consultation process } 226580 \text { and } \\
\text { revision of the ICZM Recommendation }\end{array}$ & $\begin{array}{l}\text { Is carried out in consultation with the evaluation on future } \\
\text { action on MSP (see theme Marine Spatial Planning). }\end{array}$ \\
2013 & $\begin{array}{l}\text { Draft proposal of the European Commission and } \\
\text { the Council for a directive establishing a framework } \\
\text { for maritime spatial planning and integrated coastal } \\
\text { zone management (COM (2013) 133) }\end{array}$ \\
\hline
\end{tabular}

Flemish Government, Ministry of Environment, Nature and Energy), the Coastal Division (MD\&K, Flemish Government, Department of Mobility and Public Works), and the Flanders Marine Institute (VLIZ) as a scientific partner (Flemish Government, Department of Economy, Science and Innovation). In 2009, the Marine Environment Department (Federal Public Service of Health, Food Chain Safety and Environment) also became a partner (Belpaeme 2011 208453).

Belgium is a coastal Member State with limited coastal and marine areas where a multitude of policy levels are active (see Chapter 3 of the Compendium for Coast and Sea). Given the fragmentation of competences, the integration and deliberation of sectoral visions and plans in the coastal area are crucial. In this regard, the various competent authorities each have an internal responsibility to implement ICZM. Although an administrative anchoring of ICZM in Belgium is not on the agenda (at the moment), the policy framework and the principles of ICZM are gradually incorporated into the sectoral policy for the coast.

Belgium does not have an ICZM strategy, but performs additional actions for achieving ICZM in the context of existing policies and legislation. In 2006, the validity of the recommendation (2002/413/EC) expired. In anticipation of the revision process, the Member States were asked to work on a second national report covering the period from 2006 to 2010. In 2011, the ICZM recommendation was subjected to a revision. An evaluation was carried out after 10 years of ICZM in Belgium as well (Belpaeme $2011^{208453}$ ).

\subsection{Spatial use}

ICZM cannot be regarded as a user of space; rather it is a process to optimize the spatial use in the coastal zone on land and at sea, and in particular at the interface between land and sea. The definition and delimitation of the geographical concept of 'coastal zone' was not a straightforward process both on an international and European level (EU Code of Conduct for Coastal Zones, $1999{ }^{20650}$ ). For the operation of the Coordination Centre for Integrated Coastal Zone Management in Belgium, a definition of "coastal zone" was chosen stretching from the polders to the territorial sea (figure 1).

In practice, this means that the coastal zone policy involves the 10 coastal municipalities (De Panne, Koksijde, Nieuwpoort, Middelkerke, Oostende, Bredene, De Haan, Blankenberge, (Zeebrugge), Knokke-Heist) and 9 hinterland municipalities (Damme, Brugge, Zuienkerke, Jabbeke, Oudenburg, Gistel, Diksmuide, Veurne, Alveringem and LoReninge). On the seaward side, the coastal area is bordered by the 12-mile zone.

Other definitions of the 'coast' or 'coastal zone' are available on: http://www.coastalatlas.be/en/themes/generalsetting/definitie-kust/.

\subsubsection{Implementation of the policy context in Belgium}

The fragmentation of the different competent authorities within the various policy areas and geographic areas of the coastal area constitutes a major challenge for most Member States whose target is to achieve an effective coastal zone management. This is also the case for Belgium (table 2). 


\section{DEMARCATION OF THE COASTAL AREA}

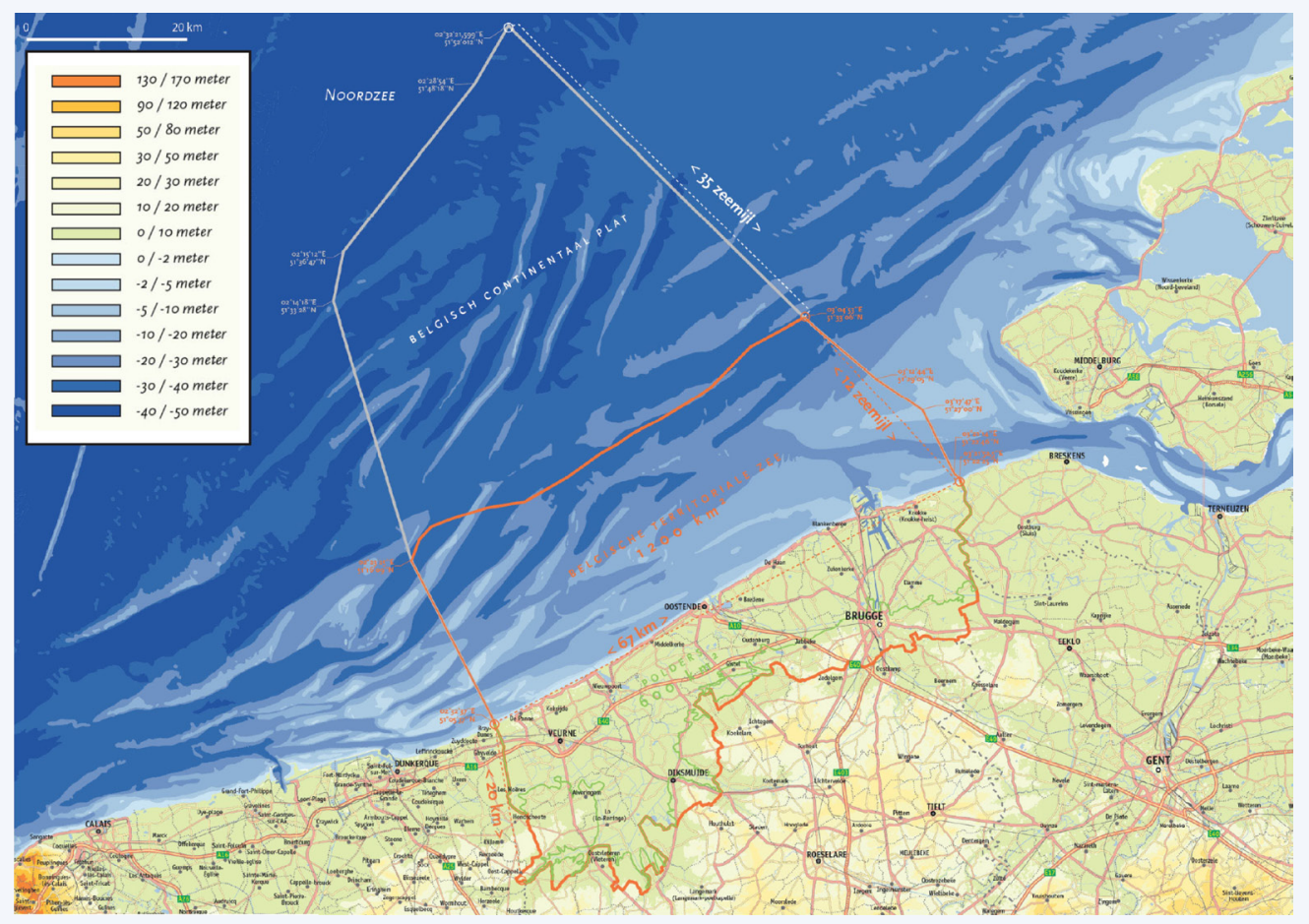

Figure 1. Demarcation of the coastal area, as defined by the Coordination Centre for Integrated Coastal Zone Management in Belgium, showing the 12-mile zone at sea and the 10 coastal municipalities and 9 hinterland municipalities on the landward side of the 'coastal zone' (www.coastalatlas.be).

The issues for integrated coastal zone management in Belgium are partly addressed in the following publications: Tussen Land en Zee: dringend... nood aan een integraal kustzonebeheer: 10-puntenprogramma voor integraal kustzonebeheer in België (Natuurreservaten vzw en WWF 1994) 19104, Belpaeme 2001 22507, Advies van de Mina-raad van 5 april 2001 over het geïntegreerd beheer van kustgebieden ${ }^{66206}$ and Cliquet et al. $2002{ }^{30285}$ (Legal inventory of the coastal zone in Belgium).

Although Belgium has no strategy for ICZM, the recommendations and the principles stipulated in the EU recommendation (2002/413/EC) are followed up by the Coordination Centre for ICZM (website). Through the Protocol (2007), the partnership of the Coordination Centre for ICZM was given an organizational structure (figure 2) and strategic objectives that are achieved through a multi-year plan.

The three strategic objectives of the Coordination Centre for ICZM are:

- To contribute to the implementation of the European Recommendation concerning the implementation of ICZM in Europe (2002/413/EC);

- To promote the integration of planning and policy in the coastal zone;

- To create a platform for integrated management of the coastal zone.

To achieve these objectives, the following operational objectives have been established:

- To communicate and raise awareness about the ICZM;

- $\quad$ To act as contact point for the ICZM;

- To provide a platform for discussion with regard to ICZM;

- To monitor the sustainability indicators of the coastal zone;

- To contribute to the achievement of the recommendations of the European Recommendation on the implementation of ICZM in Europe. 
Table 2: An overview of the competences in the coastal area in Belgium (Belpaeme et al. 2011 20733). A detailed overview of the competences with regard to the coast and sea is given in Chapter 3 of the Compendium for Coast and Sea.

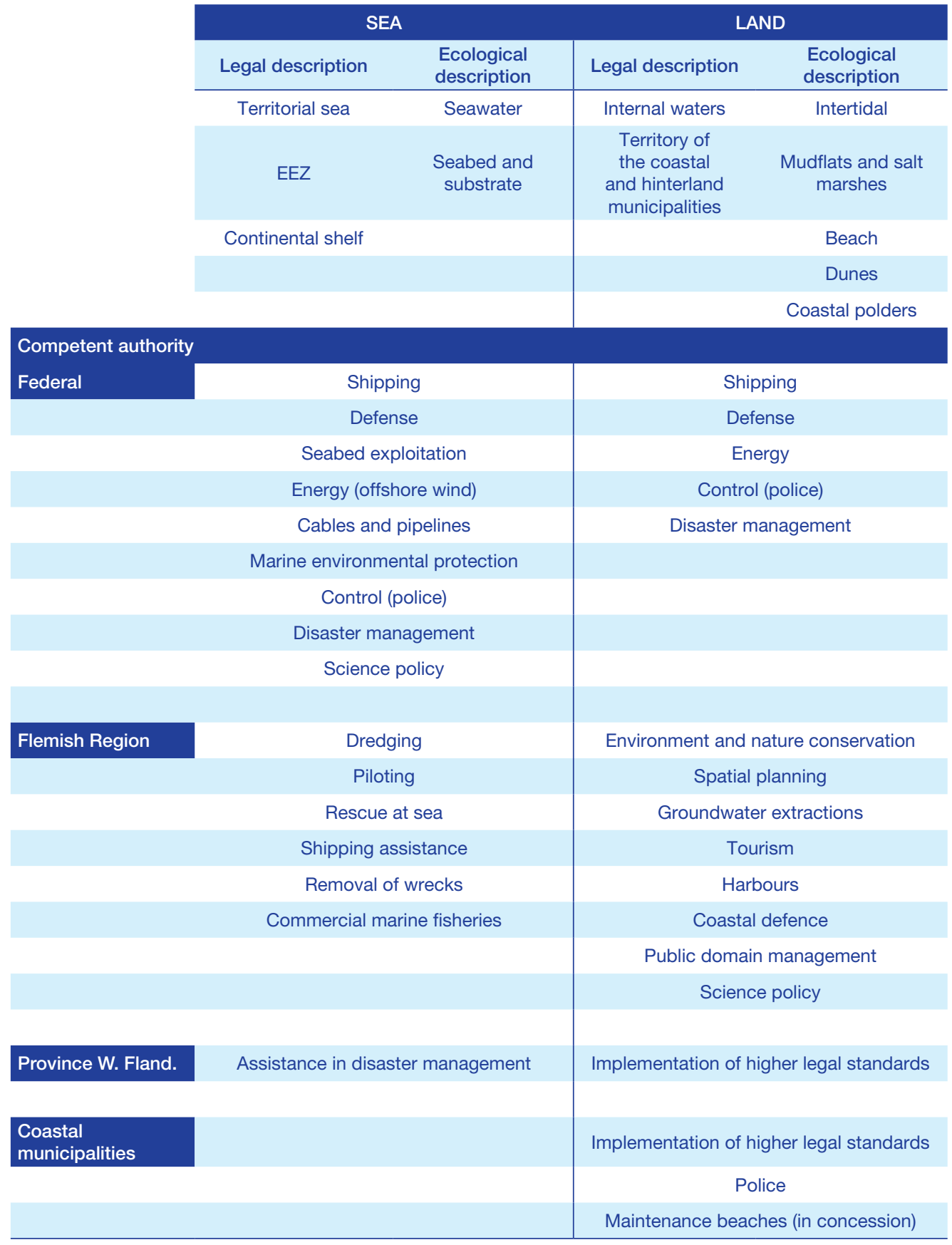

In September 2011, Belgium celebrated the $10^{\text {th }}$ anniversary of ICZM and a critical reflection was made in the publication '10 jaar Coördinatiepunt een kwestie van evenwicht' (Belpaeme 2011 208453). See also the publications: Cliquet et al. (2002) ${ }^{105155}$ and Cliquet et al. (2004) ${ }^{72542}$ for a reflection on the administrative context of ICZM in Belgium.

\subsection{Societal interest}

Integrated management does not only provide a more qualitative and sustainable policy but is, according to a scientific study by the European Commission, also cost-effective. The study shows that investments in integrated coastal management provide social benefits in the long term that are on average 10 times higher (An Assesment 


\section{ORGANISATIONAL STRUCTURE OF THE COORDINATION CENTRE FOR ICZM}

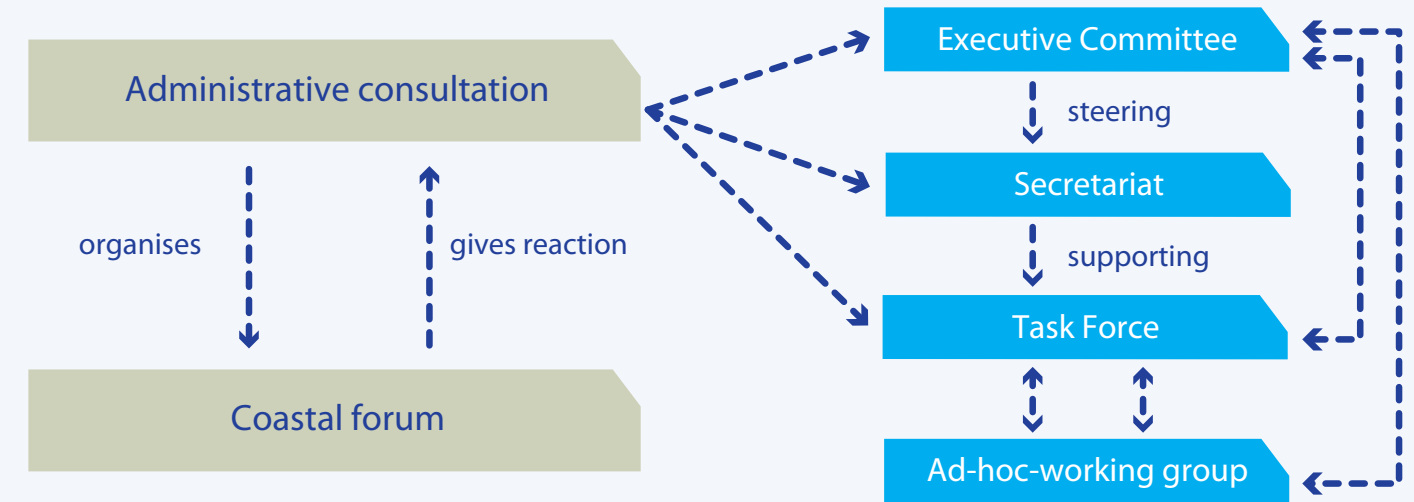

Figure 2. Organisational structure of the Coordination Centre for ICZM.

of the Socio-Economic Costs \& Benefits of Integrated Coastal Zone Management: Final Report To The European Commission, $2000^{27587}$ ). In the Belgian ICZM Recommendation Report of $2006{ }^{101811}$, a number of recommendations are made to address the coastal policy together and in a sustainable way. The stimulation of specific projects on sustainable coastal management, the use of indicators as a scientific instrument, and a higher involvement of the coastal actors through a coastal forum are some of them. A shared long-term vision for the coast is also one of the targets, as well as closer cooperation between the competent authorities. In the Belgian ICZM recommendation report of $2010^{226549}$, the realizations for the period $2006-2010$ in response to the recommendations are further elaborated (see Sustainable use).

\subsection{Sustainable use}

Based on the national reports, the European Commission concluded that a continuous effort is required to put effective ICZM in Europe into practice. An overview of 'good practices' with regard to ICZM in the EU Member States can be found in the European database OURCOAST.

\section{PERCEIVED DEGREE OF IMPLEMENTATION OF SUSTAINABLE COASTAL ZONE MANAGEMENT}

Phase 1: Planning and management are carried out in the Belgian coastal zone

Phase 2: A framework exists for the implementation of ICZM

Phase 3: Most aspects of the ICZM-approach are present and function well

Phase 4: An efficient, adapted and integrated process is embedded on all levels of government and results in a more sustainable coastal region

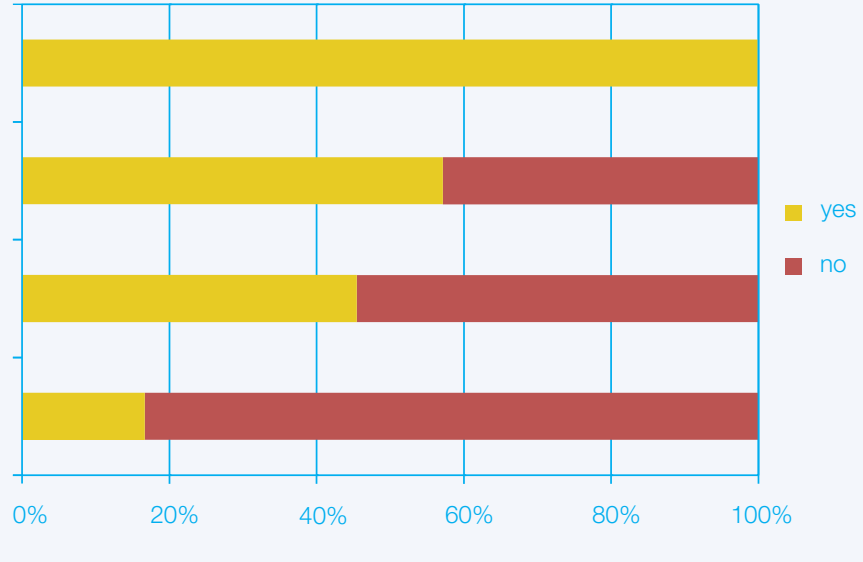

Figure 3. Perceived degree of implementation of sustainable coastal zone management (Maelfait et al. $2012{ }^{221016}$ ). 
For the monitoring of the ICZM implementation, the European Commission has developed an instrument through an ICZM Expert Group for the Member States. The 'ICZM progress indicators' were also applied in Belgium. During the first assessment, the participants-evaluators indicated that effective planning and management are carried out in the Belgian coastal zone through structural plans, monitoring, protection statutes and other legal instruments, but they equally believed that these instruments are not or insufficiently integrated (figure 3). Although all the elements for ICZM are available, the implementation of the process is still insufficient with regard to the involvement of coastal actors, openness in communication from the competent authorities and especially with regard to the legal anchoring of ICZM plans and strategies. The accessibility and timely availability of quality-controlled information to underpin coherent and effective decisions were positively evaluated (Maelfait et al. $2012^{221016}$ ).

The report '10 jaar Coördinatiepunt een kwestie van evenwicht' (Be/paeme $2011^{208453)}$ provides an overview of the main achievements and measurable effects of ICZM in the Belgian coastal area.

\subsubsection{Visions for the development of the coastal region}

Recently, several visions from different perspectives (academia, policy, industry, etc.) have been drafted for the development of the coastal zone. Some of these initiatives are listed below:

- In the policy document of the Architect of the Flemish Government, Peter Swinnen (Swinnen $2010^{226551}$ ), the coast is defined as an area with a potentially strong appeal and international recognition. The Flemish Government Architect wants to scan the architectural and spatial margins of Flanders on the coast with a study of regional or cross-border areas in the report 'Metropolitaan Kustlandschap 2100' 225477 (not finished yet).

- The Kappaplan ${ }^{220908}$ of 'Natuurpunt' provides a vision and an overview of existing and potential measures to prepare the coast for the impacts of climate change.

- In the context of a European project 'Coastal Communities $2050{ }^{128455}$ ', it has been examined whether the different visions that are currently being developed can be aligned and may reinforce each other.

- The department of Mobility and Public Works coordinates the project Flanders Bays (included in the coalition agreement of the Flemish Government, regeerakkoord van de Vlaamse regering (2009-2014) 225478). The project aims at developing a vision of the future of the Flemish coast, with the recovery of a wide and 'soft coast' and the protection against a changing environment. The vision also provides space for the development of the seaports.

- The coast as an area for development was also the basis of the CcASPAR project. The CcASPAR project (Climate change and changes in spatial structures in Flanders, funded by the Agency for Innovation by Science and Technology (IWT)) has conducted research on the spatial impact of climate change in order to formulate spatial adaptation strategies and sustainable policy implications for Flanders at different spatial scales. The strategies developed were tested on the coast and in the Yser estuary (Allaert et al. $20122^{221516}$ ).

- Initiatives of 'Oostende Werft' and the Coordination Centre for ICZM: workshop 'Beeldkwaliteit aan de Kust' (2010, website Coordination Centre) and workshop 'De Kust moderniteit' (2013). 


\section{Legislation reference list}

Table with European legislation. The consolidated version of this legislation is available on Eurlex.

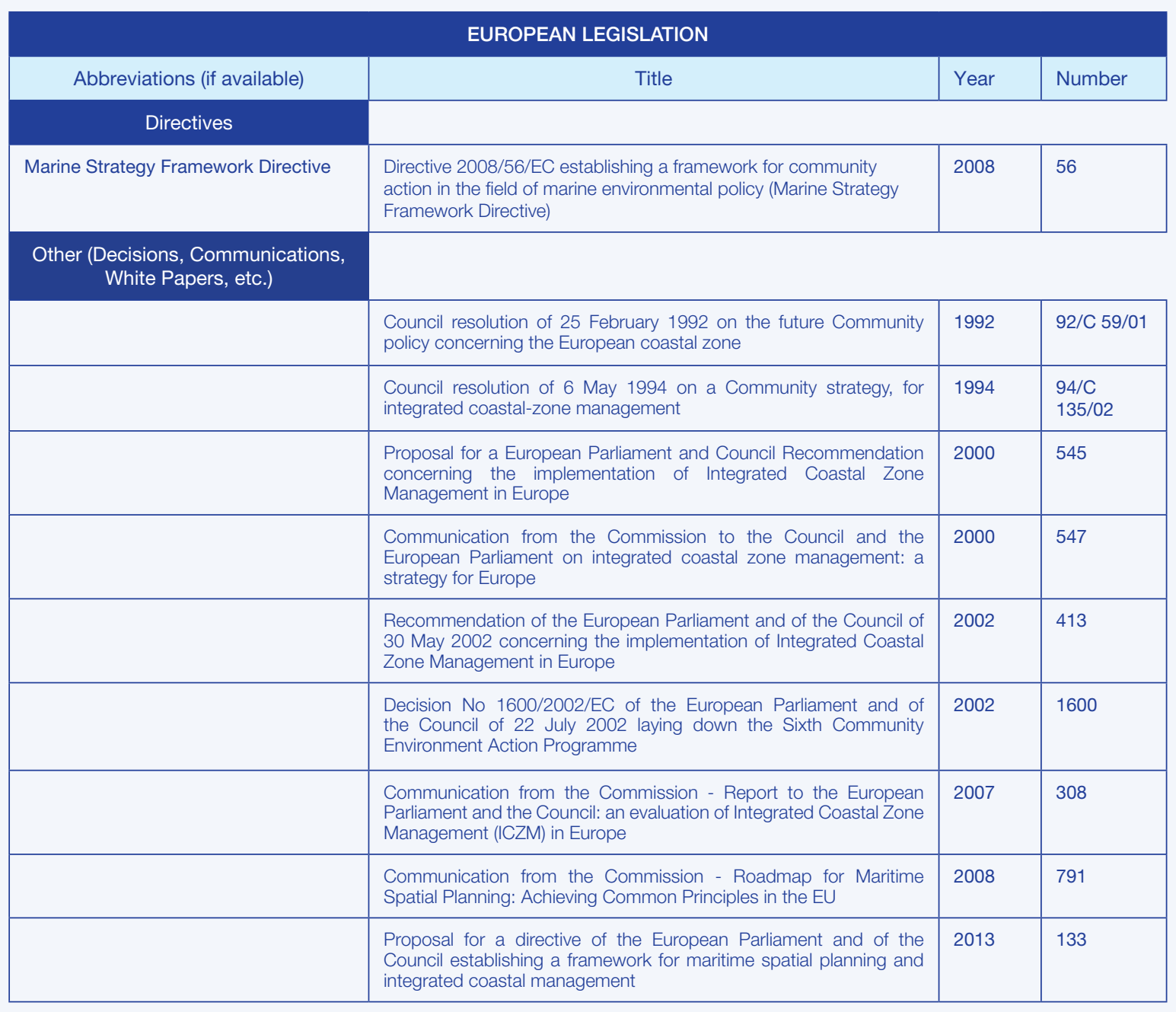


